\title{
Institutional Investors, Dividend Policy and Firm Value-Evidence from China
}

\author{
Jiacai Xiong \\ School of Accountancy, Jiangxi University of Finance and Economics, Nanchang, China \\ Email: xiongjc-p@163.com
}

Received 28 July 2016; accepted 22 August 2016; published 25 August 2016

Copyright (C) 2016 by author and Scientific Research Publishing Inc.

This work is licensed under the Creative Commons Attribution International License (CC BY). http://creativecommons.org/licenses/by/4.0/

(c) () Open Access

\begin{abstract}
The China stock market and institutional investors have experienced an extraordinary development during the past decades. Therefore, it is important to examine the real effects of institutional investors. This paper investigates relationship between institutional investors and firm value using Chinese listed companies from 2008 to 2014. This paper finds that institutional investors help improve firm value. Further analysis shows that institutional investors improve firm value by increasing cash dividend payout. The empirical results of this paper show that institutional investors help improve corporate governance and reduce agency costs.
\end{abstract}

\section{Keywords}

Institutional Investors, Firm Value, Cash Dividend, Corporate Governance

\section{Introduction}

During the past 30 years, institutional investors developed rapidly in the global financial system, and have become an important force in the capital market both in developed countries and emerging markets. In the United States, the proportion of total outstanding shares held by institutional investors increases from $6.1 \%$ in 1950 to $61.2 \%$ in 2005 . In the EU, financial assets held by institutional investors increased by $150 \%$ in the eight years from 1992 to 2000.

After 20 years of development, the Chinese capital market has made considerable progress. In early stage, individual investors dominate the market. Therefore, China Securities Regulatory Commission (CSRC) proposed the strategy of "extraordinary development of institutional investors" in 2001 since the Chinese institutional investors have experienced an extraordinarily rapid development. According to China stock market accounting research (CSMAR) database, among the A-share listed companies in China's capital market, the proportion of 
shares held by institutional investors was only $0.687 \%$ at the end of 2000 , while it jumped to $19.964 \%$ at the end of 2005 and reached $51.535 \%$ at the end of 2015 [1]. In addition, the categories of institutional investors gradually become more diversified. Securities investment funds, brokerage, insurance, and general corporate and other institutional investors have become the backbone of the securities market. Among them, the general corporate and securities investment funds account for the major share of the market.

So it is important to re-examine the reasonableness of the strategy- "extraordinary development of institutional investors. This paper investigates the relationship between institutional investors and firm value, and examines the channels through which institutional investor may affect firm value.

We find that firm value is positively correlate with the institutional investors' shareholding, and institutional investors do have a significantly help on enhancing corporate value. Furthermore, this thesis studies how institutional investors affect the value of companies from the following aspects: dividend policy. We examine the influence of institutional investors on the company's cash dividend. The empirical results show that institutional investors are conducive to enhance the company's cash dividend payment level, and it helps to reduce agency costs and inefficient use of free cash flow.

The rest of the paper is organized as follows. Section 2 reviews the existing literature and develops testable hypotheses. Section 3 describes the research design, models, variable measures, and sample. Sections 4 presents empirical results. Section 5 concludes the study.

\section{Literature Review and Hypothesis Development}

Many existing research results show that institutional investors' shareholding can significantly enhance the value of listed companies, institutional investors will active participate in supervision and management on the company's daily business operations, in order to controlling operator agent behavior and reducing the risk of the agent problem. The higher the proportion of institutional investors' shareholding is, the closer the relationship between firm value and institutional investors' shareholding is. Institutional investors will take various means of listed companies to exert a positive impact on the governance structure, in order to obtain long-term benefits of governance [2] [3]. Furthermore, institutional investors can reduce the free-riding behaviors, and have the motivation and ability to supervise the company [4].

In empirical research, Woidtke (2002) [5] found that there is a positive correlation between the proportion of private pension funds' shareholding and companies' Tobin Q. Hartzell and Starks (2003) [2] found that institutional investors oversees the signing of manager's compensation contract, which also reflects indirectly that the institutional investors can effectively supervise the behaviors of management, improve corporate governance and enhance corporate value. Gaspar and Massa (2007) [3] find that institutional investor are more effective in monitoring local firms.

Thus, we propose the first hypothesis:

Hypothesis 1: The total proportion of institutional investors' shareholding was positively correlated with the value of listed companies.

Many research results support the "effective supervision hypothesis", that is, institutional investors can enhance corporate value through active oversight of management and major shareholders behavior. On the one hand, institutional investors can participate in the decision of the dividend policy to reduce free cash flow under management control, reduce agency costs, and enhance corporate value. On the other hand, institutional investors can participate in corporate governance to enhance transparency of information, and enhance the market value of the business.

Eckbo and Verma (1994) [6] noted that institutional investors tend to pay dividends from the company's free cash flow in order to reduce the agency costs. Hongbo Wen and Shinong Wu (2007) [7] studied the relationship between the proportion of institutional investors' shareholding and the dividend policy, and found that institutional investors have an oversight function, and inhibits the behavior of listed companies' cash dividend malicious. Jinhui Luo (2013) [1] shows that, if and only if a listed company (continuously) grant (higher) cash dividend, institutional investors' shareholding can significantly enhance the company's market value, and at the same time, the proportion of institutional investors' shareholding must reach a higher level.

Hypothesis 2: The proportion of institutional investors' shareholding positively correlates with cash dividend. 


\section{Research Design}

\subsection{Sample}

The data are derived from the CSMAR database. The initial samples include published annual report data of A-share listed companies in years 2008-2014, and the samples were screened as follow: 1) Exclude financial listed companies; 2) Exclude the ST (Special treatment) companies ${ }^{1}$; 3) Exclude the companies which lack of relevant data; 4) Exclude the companies unfinished share reform. Ultimately, we get 17,565 samples in total.

\subsection{Variable Definition}

\subsubsection{Explained Variables}

This thesis selects $R O A$ and $T O B I N Q$ as dependent variables to measure and evaluate the value of listed companies. At present, the relevant empirical studies measure and evaluate enterprise value mainly from two aspects: financial and market. Therefore, we use return on assets $(R O A)$ and Tobin $\mathrm{q}(T O B I N Q)$ as the proxy variables. Furthermore, we use total dividend before tax scaled by total outstanding shares of the year to measure cash dividend payout.

\subsubsection{Explaining Variables}

We use the proportion of institutional investors' shareholding (INST) as explaining variables, which represent the ratio of total shares held by institutional investors at the end of year to total outstanding shares of the year.

\subsubsection{Control Variables}

Following Luo (2013) [1] and Woidkte (2002) [5], we takes the share proportion of the largest shareholder $(T O P)$, the square of the share proportion of the largest shareholder (TOPSQ), financial leverage (LEV), and company scale (SIZE) as control variables to control the effect of other characteristics of listed companies on the company's value. See Table 1 for variables definitions.

\section{Table 1. Variables definitions.}

\begin{tabular}{|c|c|c|}
\hline Variable & Symbol & Definition \\
\hline Tobin Q & TOBINQ & $\begin{array}{l}\text { (Closing price at the end of year } \times \text { outstanding shares }+ \text { net asset value per share } \times \\
\text { non-circulating shares }+ \text { liabilities at the end of year)/total assets at the end of year }\end{array}$ \\
\hline Return on assets & $R O A$ & Net income/total asset \\
\hline Cash dividend dummy & $D \_D I V$ & D_DIV if equal to 1 if DPS $>0$ \\
\hline Dividend per share & $D P S$ & Total dividend before tax/total outstanding shares of the year \\
\hline $\begin{array}{l}\text { The proportion of institutional } \\
\text { investors' shareholding }\end{array}$ & INST & $\begin{array}{c}\text { Total shares held by institutional investors at the end of year/total } \\
\text { outstanding shares of the year }\end{array}$ \\
\hline $\begin{array}{l}\text { The share proportion of the } \\
\text { largest shareholder }\end{array}$ & TOP & $\begin{array}{c}\text { Total shares held by the largest shareholder at the end of } \\
\text { year/total outstanding shares of the year }\end{array}$ \\
\hline $\begin{array}{l}\text { The square of the share proportion } \\
\text { of the largest shareholder }\end{array}$ & TOPSQ & $\begin{array}{c}\text { (Total shares held by the largest shareholder at the end of } \\
\text { year/total outstanding shares of the year) }\end{array}$ \\
\hline Financial leverage & $L E V$ & Total liabilities at the end of year/total assets at the end of year \\
\hline Firm scale & SIZE & Ln (total assets at the end of year) \\
\hline The growth of company & $G R$ & $\begin{array}{c}\text { Total assets growth rate }=\text { (total assets at the end of year/total } \\
\text { assets at the end of last year) }-1\end{array}$ \\
\hline Return on equity & $R O E$ & Net income/total equity \\
\hline Earnings per share & EPS & Net income/total outstanding shares of the year \\
\hline
\end{tabular}

\footnotetext{
${ }^{1}$ Shanghai and Shenzhen stock exchanges introduce the special treatment policy (ST policy) in April 22, 1998. A listed firm that reported two consecutive annual losses would be put into ST status. Therefore, ST companies can systematic different to others. So, we exclude these firms from our sample.
} 


\subsection{Models Specification}

Following Woidtke (2002) [5] and Gaspar and Massa (2007) [3], we estimate the following multivariate panel data regressions to test the effect of institutional ownership on firm value, dividend payout and earnings management.

$$
\begin{gathered}
\text { TOBINQ/ROA }=\beta_{0}+\beta_{1} I N S T+\beta_{2} T O P+\beta_{3} T O P S Q+\beta_{4} L E V+\beta_{5} S I Z E+\mu \\
D \_D I V / D P S=\beta_{0}+\beta_{1} I N S T+\beta_{2} S I Z E+\beta_{3} G R+\beta_{4} L E V+\beta_{5} R O E+\beta_{6} E P S+\mu
\end{gathered}
$$

We estimate Equation (1) and Equation (2) using ordinary least squares $(O L S)$. To correct for heteroscedasticity and with-in firm serial correlation, we adjust the standard errors using cluster at the firm level.

\section{Empirical Results}

\subsection{Description Statistics}

Table 2 reports descriptive statistics for the variables, including the mean, standard deviation, median, minimum, and maximum. Return on assets $(R O A)$ and Tobin's Q $(T O B I N Q)$ in the sample has mean of 0.045 and a median of 2.305 .

In explaining variables, the mean value of INST is $15 \%$, and the median is $34 \%$. In recent years, China's capital market flourishes and government greatly promote the development of institutional investors, which making China's institutional investors have experienced a rapid development. However, the maximum value is $73 \%$, the minimum value is $0 \%$, and the standard deviation is $19 \%$, which suggest that the variation of the proportion of institutional investors' shareholding is lager, which is closely related to the specific circumstances of individual stocks.

\subsection{The Effect of Institutional Investors on Firm Value}

Table 3 reports panel regression estimates of Equation (1) using ROA and TOBINQ as dependent variables. As shown in Table 3, the proportion of institutional investors' shareholding (INST) significantly positively correlates with $R O A$ and $T O B I N Q$ at $1 \%$ confidence level. It suggests that institutional investors' shareholding is conducive to enhance the company's value, through participating in corporate governance and supervising management reduce short-term behavior of management and enhance the company's long-term value.

The market value indicator TOBINQ and financial leverage have a significant positive correlation, and the financial value indicator $R O A$ and financial leverage have a significant negative correlation, which indicates that financial leverage will help to enhance the company's market value, but is not conducive to enhancing the book value. Firm size and the value of company have a significant negative correlation, indicating that the company which a large scale is unfavorable to enhance the corporate value.

\begin{tabular}{|c|c|c|c|c|c|}
\hline Variable & Mean & Standard deviation & Min & Median & $\operatorname{Max}$ \\
\hline TOBINQ & 2.305 & 4.537 & 0.0874 & 1.622 & 337.6 \\
\hline$R O A$ & 0.0495 & 0.245 & -7.285 & 0.0417 & 20.79 \\
\hline$D P S$ & 0.1612 & 0.1989 & 0.0000 & 0.1000 & 6.4190 \\
\hline$I N S T$ & 0.15 & 0.19 & 0 & 0.34 & 0.73 \\
\hline$T O P$ & 0.365 & 0.157 & 0 & 0.345 & 0.990 \\
\hline TOPSQ & 0.158 & 0.130 & 0 & 0.119 & 0.980 \\
\hline$L E V$ & 0.494 & 1.247 & -0.195 & 0.446 & 96.96 \\
\hline SIZE & 21.75 & 1.349 & 13.08 & 21.60 & 28.51 \\
\hline
\end{tabular}

Table 2. Descriptive statistics. 
Table 3. Regression of firm value on institutional investors.

\begin{tabular}{|c|c|c|}
\hline & (1) $T O B I N Q$ & (2) $R O A$ \\
\hline \multirow{2}{*}{ INST } & $1.044^{* * *}$ & $0.037^{* * *}$ \\
\hline & $(0.179)$ & $(0.011)$ \\
\hline \multirow{2}{*}{ TOP } & $-0.089^{* * *}$ & $-0.002^{* * *}$ \\
\hline & $(0.009)$ & $(0.001)$ \\
\hline \multirow{2}{*}{ TOPSQ } & $11.481^{* * *}$ & $0.240^{* * *}$ \\
\hline & $(1.140)$ & $(0.065)$ \\
\hline \multirow{2}{*}{$L E V$} & $1.526^{* * *}$ & $-0.046^{* * *}$ \\
\hline & $(0.031)$ & $(0.002)$ \\
\hline \multirow{2}{*}{ SIZE } & $-1.164^{* * *}$ & $-0.007^{* * *}$ \\
\hline & $(0.026)$ & $(0.002)$ \\
\hline \multirow{2}{*}{ Cons } & $28.224^{* * *}$ & $0.243^{* * *}$ \\
\hline & $(0.596)$ & $(0.034)$ \\
\hline$N$ & 14068 & 14667 \\
\hline$R^{2}$ & 0.248 & 0.0570 \\
\hline $\operatorname{Adj}-R^{2}$ & 0.248 & 0.0570 \\
\hline$F$ & 929.0 & 178.2 \\
\hline
\end{tabular}

Note: Robust standard errors that are clustered by firm are present in parentheses under the coefficients. ${ }^{* * *},{ }^{* * *}$ respectively stands for $10 \%, 5 \%$ and $1 \%$ statistically significant.

\subsection{The Effect of Institutional Investors on Cash Dividend Payout}

Table 4 reports panel regression estimates of Equation (1) using D_DIV and DPS as dependent variables. As shown in Table 4, cash dividend dummy $\left(D_{-} D I V\right)$ and cash dividend dummy per share (DPS) are both significantly positively correlates with the proportion of institutional investors' shareholding (INST) at 10\% or above confidence level, indicating that institutional investors' shareholding is conducive to improve the company's cash dividend payment, in order to reduce the inefficient investment and the agent proxy costs caused by redundant free cash flow. It is consistent hypothesis 2 . It also suggests that institutional investors can enhance the corporate value through participating in corporate governance, and affecting the decision process of cash dividend.

\section{Conclusions}

The paper studies the influence of Chinese institutional investors on firm value. Firstly, it carried on an empirical research on the relationship between the proportion of institutional investors' shareholding and corporate value by establishing a multiple linear regression model, to verify whether there is a significant correlation, and concluded: the proportion of institutional investors' shareholding (INST) significantly positively correlates with ROA and TOBINQ, and institutional investors' shareholding is conducive to enhance the company's value, by participating in corporate governance and monitoring the management.

Secondly, it studied how institutional investors affect the value of companies by increasing cash dividend payout. We find that institutional investors' shareholding is conducive to improve the company's cash dividend payment, in order to reduce the inefficient investment and the agent proxy costs caused by redundant free cash flow, and institutional investors can enhance the corporate value through participating in corporate governance, and affecting the decision process of cash dividend. 
Table 4. Regression of cash dividend per share on institutional investors.

\begin{tabular}{|c|c|c|}
\hline & (1) $D \_D I V$ & (2) $D P S$ \\
\hline \multirow{2}{*}{$I N S T$} & $0.100^{* * *}$ & $0.012^{*}$ \\
\hline & $(0.019)$ & $(0.007)$ \\
\hline \multirow{2}{*}{ SIZE } & $0.016^{* * *}$ & $0.004^{* * *}$ \\
\hline & $(0.003)$ & $(0.001)$ \\
\hline \multirow{2}{*}{$G R$} & $0.007^{* *}$ & $0.018^{* * *}$ \\
\hline & $(0.003)$ & $(0.002)$ \\
\hline \multirow{2}{*}{$L E V$} & $-0.008^{* * *}$ & $-0.153^{* * *}$ \\
\hline & $(0.003)$ & $(0.008)$ \\
\hline \multirow{2}{*}{$R O E$} & $0.032^{* * *}$ & $-0.277^{* * *}$ \\
\hline & $(0.006)$ & $(0.025)$ \\
\hline \multirow{2}{*}{$E P S$} & $0.055^{* * *}$ & $0.290^{* * * *}$ \\
\hline & $(0.008)$ & $(0.006)$ \\
\hline \multirow{2}{*}{$U P P S$} & $0.112^{* * *}$ & $-0.009^{* * *}$ \\
\hline & $(0.003)$ & $(0.002)$ \\
\hline \multirow{2}{*}{ cons } & $0.177^{* * *}$ & 0.0250 \\
\hline & $(0.059)$ & $(0.027)$ \\
\hline$N$ & 14741 & 14741 \\
\hline$R^{2}$ & 0.212 & 0.558 \\
\hline $\operatorname{Adj-R^{2}}$ & 0.211 & 0.558 \\
\hline$F$ & 564.6 & 1781 \\
\hline
\end{tabular}

Note: Robust standard errors that are clustered by firm are present in parentheses under the coefficients. ${ }^{*},{ }^{* *},{ }^{* * *}$ respectively stands for $10 \%, 5 \%$ and $1 \%$ statistically significant.

\section{Acknowledgements}

I acknowledge financial support from the National Natural Science Foundation of China (Grant No. 71562015), Postdoctoral Science Foundation of China (Grant No. 2015M571985), Postdoctoral Science Foundation of Jiangxi Province (Grant No. 2015KY25), Social Science Foundation of Jiangxi Province (Grant No. 15GL29), Social Science University Humanity of Jiangxi Province (Grant No. GL1522).

\section{References}

[1] Luo, J.H. (2013) Institutional Investors, Cash Dividend Policy and Firm Value: Evidence from China. Investment Research, 1, 56-74. (In Chinese)

[2] Hartzell, J.C. and Starks, L.T. (2003) Institutional Investors and Executive Compensation. Journal of Finance, 58, 2351-2374. http://dx.doi.org/10.1046/j.1540-6261.2003.00608.x

[3] Gaspar, J.M. and Massa, M. (2007) Local Ownership as Private Information: Evidence on the Monitoring-Liquidity Trade-Off. Journal of Financial Economics, 84, 751-792. http://dx.doi.org/10.1016/j.jfineco.2005.10.010

[4] Shleifer, A. and Vishny, R.W. (1986) Larger Shareholders and Corporate Control. Journal of Political Economy, 94, 461-488. http://dx.doi.org/10.1086/261385

[5] Woidtke, T. (2002) Agents Watching Agents: Evidence form Pension Fund Ownership and Firm Value. Journal of Financial Economics, 63, 99-131. http://dx.doi.org/10.1016/S0304-405X(01)00091-5

[6] Eckbo, B.E. and Verma, S. (1994) Managerial Share Ownership, Voting Power, and Cash Dividend Policy. Journal of 
Corporate Finance, 1, 33-62. http://dx.doi.org/10.1016/0929-1199(94)90009-4

[7] Wen, H.B. and Wu, S.N. (2007) Institutional Investors, Corporate Governance and Dividend Policy. China Accounting Review, 5, 367-380. (In Chinese)

\section{Submit or recommend next manuscript to SCIRP and we will provide best service for you:}

Accepting pre-submission inquiries through Email, Facebook, LinkedIn, Twitter, etc.

A wide selection of journals (inclusive of 9 subjects, more than 200 journals)

Providing 24-hour high-quality service

User-friendly online submission system

Fair and swift peer-review system

Efficient typesetting and proofreading procedure

Display of the result of downloads and visits, as well as the number of cited articles

Maximum dissemination of your research work

Submit your manuscript at: http://papersubmission.scirp.org/ 